\title{
O PROFESSOR DE PORTUGUÊS E OS FENÔMENOS LINGUISTICAMENTE COMPLEXOS: PRECONCEITO, INTOLERÂNCIA OU IGNORÂNCIA?
}

\author{
Thiago Benitez de Melo * \\ Maria Elena Pires Santos **
}

\begin{abstract}
Resumo: O propósito deste trabalho é investigar, por meio de práticas discursivas, as crenças e atitudes de alguns professores de português em relação a determinados fenômenos linguísticos frequentemente discriminados dentro e fora da sala de aula. Para tanto, foi realizada uma entrevista estruturada com três professores com o intuito de refutar e contestar algumas crenças e atitudes linguísticas imbuídas e visíveis na maior parte dos professores de língua materna. Os estudos a respeito dos fenômenos linguisticamente complexos realizados por autores como Faraco (2001), Bortoni-Ricardo (2004), Perini (2004) e Crystal (2005) subsidiam a hipótese de que tais fenômenos não são "contaminações e pragas que contribuem para o caos linguísticos", mas manifestações inerentes à língua. A pesquisa em questão é de cunho qualitativo/interpretativista e orientou-se no aparato teórico da Linguística Aplicada e da Sociolinguística.
\end{abstract}

Palavras-chave: Língua. Ensino. Fenômenos Linguísticos.

\begin{abstract}
The purpose of this study is to investigate, by means of discursive practices, beliefs and attitudes of some teachers of Portuguese for certain linguistic phenomena often broken inside and outside the classroom. Therefore, a structured interview was conducted with three teachers in order to refute and challenge some mistaken beliefs steeped in educator. Studies about the complex linguistic phenomena by authors like Faraco (2001), Bortoni-Ricardo (2004), Perini (2004) and Crystal (2005) supporting the hypothesis that these phenomena are not "pests and contaminants that contribute to the linguistic chaos", but manifestations inherent in language. The research in question is a qualitative/interpretive and guided by the theoretical apparatus of Applied Linguistics and Sociolinguistic.
\end{abstract}

Keywords: Language. Teaching. Linguistic Phenomena.

\footnotetext{
* Licenciado em Letras Português/Espanhol pela Universidade Estadual do Oeste do Paraná e mestrando em Linguagem e Sociedade, na área de concentração "Práticas Linguísticas, Culturais e de Ensino" na mesma Universidade. Contato: thiago_benitez@hotmail. com

** Doutora e pós-doutora em Linguística Aplicada pela UNICAMP, professora do Curso de Pós-graduação Strictu Sensu em Letras e do Curso de Graduação em Letras da Universidade Estadual do Oeste do Paraná. Contato: mel.pires@ hotmail.com
} 


\section{Introdução}

Muito já se discutiu, e ainda se discute, sobre intolerância linguística na escola, na mídia e na sociedade em geral. Linguistas aplicados, pedagogos, antropólogos, etnógrafos, cientistas sociais, entre outros pesquisadores, constantemente propõem políticas educacionais que respeitem a diversidade linguística e cultural do aluno. Frequentemente é lançado um novo livro com métodos e "fórmulas mágicas" que prometem revolucionar o ensino de língua materna, ensinar "definitivamente" a língua portuguesa aos alunos sem o uso da gramática normativa e erradicar de uma vez por todas as intolerâncias linguísticas no ambiente escolar por meio do ensino da variação linguística.

A gramática normativa passou a ser um instrumento de poder e de controle e, assim, "surgiu essa concepção de que os falantes e os escritores da língua é que precisam da gramática, como se ela fosse uma espécie de fonte mística invisível da qual emana a língua 'bonita', 'correta' e 'pura"” (BAGNO, 1999, p. 64). Quando falamos em língua estamos nos referindo a um produto artificial socialmente constituído, um "instrumento" construído por meio dos hábitos culturais de um povo e de suas relações sociais. Fenômenos linguísticos, estruturas linguísticas diferentes daquelas recorrentes na norma culta, na gramática normativa, são vistos, pela maior parte da sociedade, como erros absurdos e desvios gramaticais que devem ser rejeitados e erradicados pelos professores de português. As pessoas acreditam, como bem coloca Rocha (cf. 2007), que existem três livros "sagrados" que devem permanecer intocados por toda a eternidade: a Bíblia, a Constituição e a Gramática. Contrariar esta última seria uma atitude de apostasia, um crime de danos à pátria, uma heresia. Como se, ao banirmos a gramática normativa do ambiente escolar, estivéssemos renegando a nossa própria língua mãe.

Levando em conta a importância da reflexão social e linguística, e também com a finalidade de dar visibilidade ao contexto sociolinguisticamente complexo de sala de aula, especificamente nas aulas de língua materna, o objetivo que aqui colocamos é investigar, por meio de práticas discursivas, as crenças e atitudes de alguns professores de língua portuguesa em relação a determinados fenômenos linguísticos complexos frequentemente discriminados dentro e fora da sala de aula. Estamos chamando aqui de "fenômenos linguisticamente complexos" determinadas manifes- 
tações linguísticas que têm causado polêmica na atualidade, sobretudo nas aulas de Língua Portuguesa: o internetês, o caipirês, o gerundismo e os estrangeirismos respectivamente. Para tanto, foram desenvolvidas entrevistas estruturadas, gravadas em áudio (e depois transcritas), com três professores de português da rede pública de ensino (um de Ensino Fundamental, um de Ensino Médio e um professor de Magistério). A pesquisa em questão é de cunho qualitativo/interpretativista e orientou-se no aparato teórico da Linguística Aplicada e da Sociolinguística, especificamente nos seguintes autores: Faraco (2001), Bortoni-Ricardo (2004), Perini (2004), Crystal (2005), Bagno (2003, 2007), entre outros.

Este texto está dividido em três seções. Na primeira seção trazemos alguns conceitos teóricos a respeito da diferença entre preconceito linguístico e intolerância linguística, mostrando que ambos discriminam, cada um de sua maneira, os falantes de determinada língua. Na segunda, expomos algumas reflexões sobre a intolerância linguística e seus efeitos, diretos e indiretos, no ensino de língua portuguesa. Na terceira seção, apresentamos uma entrevista com os professores e algumas análises sócio(linguísticas) a partir de seus enunciados. Finalizamos, trazendo algumas considerações complementares.

\section{Preconceito ou Intolerância?}

Conta-se que, já no século XVI, o imperador espanhol Carlos I (e também Carlos V na Inglaterra) falava aos homens em francês, em alemão a seus cavalos e em espanhol a Deus. Histórias como essas se perpetuaram por séculos e atitudes parecidas não são difíceis de encontrar na atualidade; em outras palavras, casos de intolerância linguística assolam a humanidade há muito tempo. É surpreendente pensar que há alguns anos algumas línguas locais foram proibidas de serem faladas com base na ideia de que línguas e raças são inseparáveis e, portanto, uma raça inferior possui língua inferior. Fiorin (2001, p. 110) argumenta que

\footnotetext{
A história nos ensina que uma das formas de dominação de um povo sobre outro se dá pela imposição da língua, porque é o modo mais eficiente, apesar de geralmente lento, para impor toda uma cultura - seus valores, tradições, inclusive o modelo socioeconômico e o regime político.
}

No Brasil, por exemplo, os colonizadores portugueses implantaram uma verdadeira política linguística, por meio não só das armas, mas tam- 
bém de leis que pressionavam e obrigavam à adoção do português em todo o país (cf. GREGOLIN, 2007). Casos assim acontecem porque:

A sociedade reage de maneira particularmente consensual quando se trata de questões linguísticas: ficamos unanimemente chocados diante da palavra inadequada, da concordância verbal não realizada, do estilo impróprio à situação de fala. A intolerância linguística é um dos comportamentos sociais mais facilmente observáveis, seja na mídia, nas relações sociais cotidianas, nos espaços institucionais etc. (ALKMIM, 2008, p. 42).

No entanto, a intolerância linguística é somente uma denominação "bonita" para um profundo e verdadeiro "preconceito social": não é a maneira de falar que sofre preconceito, mas a identidade social e individual do falante. Ele é discriminado segundo critérios inexistentes de padrões linguísticos, que acabam gerando critérios sociais. A profissão do indivíduo, onde mora, como se veste, de que maneira se comporta e o que possui influenciam em seu julgamento linguístico.

Leite (cf. 2008), ao tratar do preconceito linguístico, propõe que o diferenciemos de intolerância na linguagem. Para a autora, embora se pareçam sinônimos, há uma grande diferença entre ambos, pois o preconceito

é a ideia, a opinião, o sentimento que pode conduzir o indivíduo a intolerância, à atitude de não admitir opinião divergente e, por isso, à atitude de reagir com violência ou agressividade a certas situações. O preconceito é a discriminação silenciosa e sorrateira que o indivíduo pode ter em relação à linguagem do outro: é um não-gostar, um achar-feio ou achar-errado um uso (ou uma língua), sem a discussão do contrário, daquilo que poderia configurar o que viesse a ser bonito ou correto. É um não-gostar sem ação discursiva clara sobre o fato rejeitado. A intolerância, ao contrário, é ruidosa, explícita, porque, necessariamente, se manifesta por um discurso metalinguístico calcado em dicotomias, em contrários, como, por exemplo, tradição x modernidade, saber x não-saber e outras congêneres [grifos da autora] (LEITE, 2008, p. 24).

O preconceito pode ser construído culturalmente de forma naturalizada, transformando-se em rejeição e podendo vir a se manifestar como intolerância. Já a intolerância, é resultado da crítica, nascendo de julgamentos. Em suma, o preconceito não surge exclusivamente de uma dicotomia; a intolerância, por sua vez, nasce necessariamente de julgamentos de 
contrários, e se manifesta discursivamente. Para que evitemos um e outro, torna-se de primordial importância que suas causas sejam trazidas para a discussão, partindo do contexto educacional para o contexto social mais amplo.

\section{Intolerância Linguística e Ensino de Língua Portuguesa}

Comumente nos deparamos com professores de língua portuguesa indignados e perplexos com os "erros absurdos de português" de seus alunos, com "desvios gramaticais que doem no ouvido". Muitos deles (senão a maioria) acreditam e propagam o mito linguístico de que é preciso saber gramática para falar e escrever bem (cf. BAGNO, 1999). Como afirma Bagno (2003), as gramáticas foram escritas, em um primeiro momento, para descrever e fixar como "regras" e "padrões" as manifestações linguísticas usadas espontaneamente pelos escritores considerados dignos de admiração, modelos a serem imitados. Em outras palavras, a gramática normativa é decorrência da língua, é subordinada a ela, dependente dela, não vive por si só. Scherre (2008) deixa bem claro que, na verdade, não se ensina língua portuguesa ao aluno, porque não se pode ensinar o que já se sabe. Quando o professor de português está ensinando gramática normativa, ele não está ensinando língua materna, pois essa se adquire. Costa (2007, p. 11) indaga:

que ambientes frequenta a nossa norma-padrão? Manuais de redação dos considerados grandes jornais do país? A escrita de nossos jornalistas, literatos, cientistas? Os discursos dos nossos políticos? Os telejornais, as tele-entrevistas? Os arrazoados e normas dos juristas? A pregação religiosa? A fala ou a escrita de profissionais de todas as partes do País? Quem deve ser tomado como modelo?

São indagações e reflexões como essas que poderiam ajudar, e muito, o professor de português a perder algumas atitudes e crenças que insistem em perpetuar e prejudicar o aprendizado, desrespeitando a identidade linguística e cultural do aluno.

Por outro lado, observamos professores de língua materna e autores do campo da Linguística Aplicada que se dizem "modernos", "atualizados", que condenam a gramática escolar, mas não conseguem se livrar de suas amarras e não apresentam alternativas viáveis ao estudo da língua materna sem jugo da gramática (ROCHA, 2007). Esquecem-se de que "a língua é um fenômeno cultural, histórico, social e cognitivo que varia ao longo do 
tempo e de acordo com os falantes: ela se manifesta no seu funcionamento e é sensível ao contexto. Não é um sistema monolítico e transparente, para 'fotografar' a realidade" (MARCUSCHI, 2008, p. 240).

Muitos de nós, professores, caímos no equívoco de correlacionarmos gramática a velhos preceitos da velha tradição excessivamente conservadora pseudopurista, de uma preocupação normativa, como muito tem acontecido no ensino de língua portuguesa em nossas escolas, o que tem contribuído para que a intolerância linguística se instale e permaneça não só no ambiente escolar, mas também na sociedade como um todo. No entanto, como nos alerta Bortoni-Ricardo (2004), quando ignoramos a multiplicidade cultural e linguística, contribuímos para que sejam ampliadas as diferenças sociais, desrespeitamos e desvalorizamos a identidade e a cultura dos nossos alunos e, concomitantemente, dos indivíduos que fazem parte de suas relações sociais. Não há mais como negar a necessidade de "superar os limites pedagógicos próprios de um processo de transição entre diferentes paradigmas educacionais. As atuais exigências sociais impõem a revisão de paradigmas" (BATISTA, 2003, p. 42).

\section{O Professor de Português e os Fenômenos Linguisticamente Complexos}

A língua, inegavelmente, é um sistema auto-regulador, ela mesma dá conta de suas necessidades. Ela mesma acolhe o que tem de serventia e descarta o que é indispensável, ela não precisa ser defendida, muito menos defendida de seus próprios falantes, que são seus legítimos usuários (cf. BAGNO, 2001). Os falantes, no processo de aquisição da linguagem, podem plenamente marcar novos parâmetros para antigos valores da língua, fazendo com que determinadas estruturas passem a significar novas possibilidades de interpretação. (cf. MACHADO FILHO, 2005). Acontece que alguns professores insistem em proibir e vetar o uso de determinados fenômenos linguísticos que, na atualidade, estão cada vez mais visíveis e recorrentes. Fizemos a seguinte pergunta a três professores de português da rede pública de ensino (os nomes dos professores - Sandra, Juliana e Fabio - são fictícios, para garantir o anonimato.): "O que você acha do internetês, a linguagem da internet, e do caipirês, o dialeto caipira? O que você diz aos seus alunos a respeito?". As respostas que obtivemos foram as seguintes:

A linguagem da internet pra mim é toda errada, né? Escrevem errado... enfim, só escrevem, nè? Escrevem errado. Aquelas gírias deles que não dá pra entender nada. Agora, quanto ao 
caipirês, eu já não considero que é erro, porque ele aprendeu a falar conforme a região que ele... que ele nasceu, que ele convive ali. Ele fala da maneira que ele aprendeu, da região dele, né? (Sandra)

O caipirês é aquela linguagem que... de um determinado local, do campo, de uma região do País, né? São variações lingüísticas, dentro da gramática, da linguagem padrão, elas são variações. Eu sempre peço pros meus alunos tomarem muito cuidado pra não acostumarem com a linguagem da internet porque ela vicia e você, viciado naquilo, você, quando vai escrever, tem aquele vício de linguagem, e usa isso dentro do teu vocabulário escrito. E isso é um erro que não é aceitável. (Juliana)

A internet acabou sendo muito utilizada pra comunicação, usando canais como msn, orkut e outros recursos de interação, e ela pegou muito da oralidade e adaptou esses recursos da oralidade para a língua escrita no campo da comunicação. E como também é muito utilizada pelos jovens, ela pegou muito as gírias, os recursos da comunicação própria dos jovens. Então o internetês seria essa linguagem: jovem, muito contaminada, digamos assim, pela oralidade, que é interessante de se expressar naquele meio, mas que, em outros lugares, ela não vai cumprir com sua função, né? Quando o aluno precisar de recursos mais formais, ela não vai ser suficiente. $E$ o caipirês, digamos, é quando você percebe que as pessoas, nas cidades, começam a usar um sotaque caipira por influência da música ou uma cultura regional, né? Começa-se a difundir essa cultura. No uso da comunicação diária não há problema algum. O problema é quando ele precisa se expressar numa linguagem mais aberta, uma linguagem mais abrangente, e aí, naturalmente, ele não vai poder usar esses recursos. (Fabio)

A linguagem da internet, desde o seu princípio, foi radicalmente discriminada. Tentou-se muito censurá-la, como se fosse uma anarquista linguística, uma nova linguagem que surgiu para acabar de vez com a nossa "pobre língua mãe" e impossibilitar de uma vez por todas o aprendizado da língua portuguesa pelos alunos. No entanto, Crystal $(2005$, p. 8) afirma que a linguagem da internet é:

um novo tipo de comunicação via Internet que não é nem a linguagem escrita, nem a linguagem falada, e que subleva as regras do mundo da escrita, usando abreviaturas de palavras e recursos gráficos para vivo e falado o que está escrito na tela do computador. 
Por meio das falas das professoras Sandra e Juliana conseguimos perceber como alguns fenômenos linguísticos (sobretudo a linguagem da internet), são totalmente condenáveis pelos professores entrevistados: "A linguagem da internet, pra mim, é toda errada"/ "não dá pra entender nada" (Sandra). "É pobre de recursos"/ "vício de linguagem"/ "é um erro que não é aceitável" (Juliana).

A linguagem da internet é uma realidade indiscutível e presente no vocabulário (podemos até dizer na Gramática Internalizada) de cada aluno, é um dos desafios com que o professor tem de aprender a lidar no século XXI. Aos linguistas, e também aos professores, cabe a procura de maior entendimento dessa linguagem, a preocupação de assumir sua responsabili dade social para garantir os direitos linguísticos da população, a salvaguarda das variantes linguísticas muitas vezes discriminadas (cf. CRYSTAL, 2005).

Ao afirmar que quem usa a linguagem da internet escreve "gírias que não dá pra entender nada", a professora Sandra esquece-se do fato de que

(...) as pessoas, quando falam ou escrevem, não têm liberdade total de inventar, cada uma a seu modo, as palavras que dizem, nem têm a liberdade irrestrita de colocá-las de qualquer lugar nem de compor, de qualquer jeito, seus enunciados. Falam, isso sim, todas elas, conforme as regras particulares da gramática de sua própria língua. Isso porque toda língua tem sua gramática, tem seu conjunto de regras (ANTUNES, 2003, p. 85).

Além disso, é inegável que todo falante nativo de português produz sentenças bem formadas, que estão de acordo com as regras do sistema da língua que esse falante internalizou, e isso independe de sua posição social. A professora Juliana classifica a linguagem da internet como "um erro que não é aceitável". Bagno (2004, p. 8) indaga: "Como chamar de erro um fenômeno que se verifica de norte a sul do país? Como milhões de falantes conseguiram 'combinar' para 'errar' todos da mesma maneira?'. Muito já se discutiu a respeito da noção de erro, mas parece não estar bem claro para alguns professores que 'a noção de 'erro' nada tem de linguística é um (pseudo)conceito estritamente sociocultural, decorrente dos critérios de avaliação que os cidadãos pertencentes à minoria privilegiada lançam sobre todas as outras classes sociais" (BAGNO, 2004, p.8). Uma língua, qualquer língua, “é sempre exata e inexata, dependendo do campo lexical 
e das circunstâncias em que os falantes a utilizam" (POSSENTI, 2001, p. 169). Dicotomias, referentes à (língua)gem, como correto/incorreto, bonito/feio e difícil/fácil são socialmente construídas, padrões estabelecidos através dos anos, mas que não possuem nada de "científico", "real" ou "verdadeiro". Como assevera (BORTONI-RICARDO, 2004, p. 71): "Todas as sentenças produzidas pelos falantes de uma língua são bem formadas, independentemente de serem próprias da chamada língua-padrão ou de outras variedades".

Apenas fortalecemos essa falsa noção de erro ao tentarmos imbuir no aluno conceitos de uma língua intangível, intocável, inalcançável. Da mesma forma que a linguagem da internet, a linguagem, ou variante, do caipira também não é muito bem vista por muitos professores: Alguns deles afirmam que essa variante da língua portuguesa é apenas uma variação linguística que o aluno, oriundo da zona rural, traz consigo e que deve ser respeitada. Consideram como um "dialeto" que representa a cultura e a história de um aluno. No entanto, essas afirmações não passam do jargão do politicamente correto. Percebemos na fala do professor Fabio o estereótipo e a representação do caipirês pela maioria dos brasileiros: "o caipirês, digamos, é quando você percebe que as pessoas, nas cidades, começam a usar um sotaque caipira por influência da música ou uma cultura regional, né?” (Fabio). A linguagem das pessoas que residem no campo ainda é vista como exótica, como um dialeto "engraçado", utilizado para provocar o riso nas telenovelas e presentes em canções que quase sempre são rejeitadas pela maior parte do público.

Apesar de tudo, percebemos que os professores se esforçam para trabalhar essa variante da língua em sala de aula. O que acontece, no entanto, é que ao invés do aluno conhecer a cultura e a linguagem real do caipira, ele acaba por impregnar estereótipos que há tempos estão presentes na sociedade brasileira. O professor leva em sala de aula o gibi do personagem Chico Bento do Mauricio de Sousa e canções sertanejas de raiz dizendo que esses materiais são a representação fiel da fala do caipira. Bem sabemos que as próprias tirinhas do personagem Chico Bento, criado por Maurício de Sousa, continuam aparecendo nos livros didáticos de língua portuguesa para representar a fala rural, que, segundo os autores desses livros, é uma fala igual a das pessoas que moram no campo e não deve ser estigmatizada. Segundo Faraco (2007, p. 43):

Parece que não há livro didático hoje que não tenha uma tira do Chico Bento - que, diga-se de passagem - está muito longe de representar, de fato, uma variedade do português rural. 
(...) o tratamento do português rural se faz pelo lado anedótico e, pior, reforçando estereótipos e não contribuindo para a compreensão histórica, social e cultural das diferenças entre os falantes urbanos e falantes rurais. Do mesmo modo, pouco contribuem para a crítica dos preconceitos que recobrem os falantes rurais.

Um último parecer sobre o caipirês nos permite afirmar que a fala do Chico Bento não é, de forma alguma, uma representação fiel da fala regional, é uma fala estereotipada do caipira (cf. BAGNO, 2003). Não estamos querendo dizer que o autor Mauricio de Sousa tem a obrigação de representar fielmente a fala de seus personagens, mas estamos considerando que é papel do professor ter cuidado com as escolhas que faz em sala de aula. Em relação às canções sertanejas, temos que ter bem claro que essas canções não são apenas compostas e cantadas por quem mora no campo e, muito menos ainda, não é apenas esse tipo de música que é escutada pelo caipira.

É aí que entra o papel social dos linguistas, e também do professor de português (o qual, para nós, "deveria" ser um constante pesquisador da linguagem). Crystal (2005) assevera que o desafio do século XXI, para aqueles que pesquisam a linguagem, sobretudo linguistas e professores de língua portuguesa, consiste não só em buscar um maior entendimento da linguagem humana, mas também em assumir sua responsabilidade social para garantir os direitos linguísticos das populações minoritárias, a lutar pela defesa das línguas ameaçadas de extinção e das variantes dialetais muitas vezes discriminadas. Isso inclui a variante rural, o caipirês, e também, é claro, a linguagem da internet, já que, para o mesmo autor, é incontestável o fato de que estamos vivenciando o início de uma revolução na linguagem, uma nova era linguística (cf. CRYSTAL, 2005). Temos de nos adaptarmos aos novos tipos de linguagem e às variantes e dialetos que surgem a cada instante em todas as línguas. A solução jamais será tentar proibir determinadas manifestações linguísticas ou tentar colocar uma mordaça nos falantes, impedir que usem algo que lhes pertence por direito, isso porque a língua não se deixa domesticar, nem aceita veto.

Passemos agora às respostas dos professores à seguinte pergunta feita no contexto da entrevista: "Você desconta nota dos seus alunos caso utilizem estrangeirismos ou gerundismos?".

Não, eu não desconto nota, mas eu... eu digo a eles, né? Como que é o certo. Hoje em dia, por causa da globalização, tudo é aceitável. Então eu não posso descontar notas dos alunos, 
mas também eu não posso dizer pra eles que eu aceito. Eu digo a eles que o correto não é esse. Mas não vou prejudicar eles por causa disso?, de forma alguma. Mas eu procuro mostra pra eles o certo né? (Sandra)

Não, eu só procuro falar pra eles que utilizem... procurem usar a linguagem do nosso país, ao invés de usar muitos estrangeirismos. [E a respeito dos gerundismos?] Eu não acho legal isso aí não. Eu sempre faço exercícios pra que eles se corrijam em relação a isso. [Mas não é descontado nota, não?] Não, não, descontar nota... não. Eu mostro pra eles que não é uma linguagem bonita. É pobre de recursos, né? E é um modismo também. (Juliana)

No caso, o estrangeirismo não necessariamente, né? O estrangeirismo não necessariamente. Principalmente quando não há um termo próprio da língua portuguesa adequado, da língua portuguesa, pra... pra se utilizar. Agora, os gerundismos, normalmente nós conversamos a respeito disso, de haver recursos mais expressivos dentro da língua que possa evitar a... até porque a repetição, sonoramente, não é muito agradável. (Fabio)

Quando o assunto é "gerundismo", é fato que, a priori, as pessoas pensam, especialmente os gramáticos, que o gerúndio seja o "causador" desse fenômeno linguístico tão condenado pelos puristas. Professores acabam confundindo gerúndio com gerundismo e para fazer com que o aluno não corra o risco de cometer uma "gafe linguística", acabam por proibi-lo de usar tanto um quanto outro. Frases como: "Você está andando muito depressa" se transformam em "Você anda muito depressa" (o que bem sabemos que a última frase não tem o mesmo efeito semântico, ou o mesmo sentido, que a primeira). Dessa maneira, "o gerundismo - uma terminologia bem empregada, se for levada em consideração a carga semântica depreciativa que a expressão denota, oriunda do morfema derivacional '-ism-" - voltou a colocar o já tão sofrido gerúndio "no paredão' da estigmatização" (SERAFIM, 2008, p. 55).

Nas respostas dos professores, percebemos que a utilização dos gerundismos não é motivo para descontar nota do aluno, mas vemos também que não são "muito agradáveis" como afirma o professor Fabio, ou que são "pobres de recursos" segundo a professora Juliana. A questão é que o professor "tenta" aceitar, procura, de alguma forma, ser tolerável a esse fenômeno linguístico (que para muito professores seria mais bem classificado como vicio de linguagem), mas não consegue se desprender das amarras 
da gramática normativa e acaba estigmatizando determinada manifestação linguística.

O gerundismo é um dos fenômenos que muito bem comprova a mutabilidade da língua. Por ser um sistema vivo, ela não pode ser regulada, como já afirmamos. A língua é um sistema auto-regulador, que dá conta de suas próprias necessidades, escolhendo, ela mesma, o que é útil em seu sistema e o que não é dispensável. Atualmente, o gerundismo representa um dos maiores apartheids linguísticos. Para Serafim (2008, p. 55): “Gerundiofóbicos surgem de todos os lados, no combate ao TOG - Transtorno Obsessivo Gerundístico. Eis que surge uma metafísica do gerúndio: o gerundismo".

Schmitz (2006, p. 109) atenta que:

A polêmica em torno do gerúndio e do gerundismo mostra que faltam em nós, debates respeitosos e tranquilos entre gramáticos, linguistas, professores de português (...) com respeito a uma atualização da norma padrão. Tal debate é necessário para eliminar a defasagem entre o que é apregoado com base na "Tradição" e o que é realmente usado no dia-a-dia pelos diferentes usuários do idioma.

Quem sabe pode se tratar de um "modismo" como classifica a professora Juliana e até pode ser que existam "recursos mais expressivos dentro na língua" como afirma o professor Fabio, mas não estamos querendo dizer que devemos começar a utilizar os gerundismos incontrolavelmente e trocar todas as formas nominais dos verbos por ele. O que estamos querendo afirmar é que o professor não tem porque ver esse fenômeno linguístico como uma manifestação pobre, feia, desagradável e que "fere os ouvidos", ou melhor ainda, como um recurso que não dá conta do sistema de comunicação da língua, pois, "do ponto de vista estritamente linguístico, não há nada demais com o chamado gerundismo. Sua estrutura é perfeitamente regular: cada verbo está na posição e na forma em que estaria se, ao invés de aparecer numa trinca, aparecesse numa dupla (vou estar saindo: vou sair)" (POSSENTI, 2008, p. 9). Acontece que o fato da língua ter mudado no passado é algo aceitável, todos entendem muito bem, mas é muito difícil as pessoas aceitarem que esse processo de mudança não parou e jamais poderá parar. Temos o hábito de imaginar que a nossa língua já terminou seu processo de mudança, já está pronta e acabada para todo o sempre, amém (cf. BAGNO, 2003). Pensa-se que, assim como a fauna, a flora e os rios, a língua também deve ser salva da extinção. A língua é um processo, um fazer-se permanente e nunca concluído. 
No caso dos estrangeirismos, que é o emprego de elementos oriundos de outras línguas, percebemos que sua noção, como afirmam Garcez e Zilles (2001), é de uma suspeita de identidade alienígena, carregada de valores simbólicos relacionados aos falantes da língua que origina o empréstimo. Ao afirmar que "hoje em dia, por causa da globalização, tudo é aceitável", a professora Sandra nos permite refletir sobre dois pontos em relação aos estrangeirismos.

Primeiro, o fato de que a língua humana não pode ser controlada, isto é, "nenhuma língua existe de forma isolada. Todas as línguas em contato se influenciam mutuamente. Aquelas cujo alcance é maior exercem mais influência sobre suas línguas de contato. E uma língua global, por natureza, exerce mais influência que todas" (CRYSTAL, 2005, p. 53). É certo que já estamos lidando com as consequências da globalização, as quais erodiram o equilíbrio do poder linguístico. Em suma, as fronteiras se abriram e as regiões do mundo ficaram mais próximas umas das outras com a intensificação do processo de globalização na década de 80. Embora a tecnologia tenha contribuído fortemente para essa aproximação, a língua e a comunicação passam a ser o próximo desafio para o século XXI. Não é que tudo se tornou aceitável por causa da globalização, mas o que acontece é que não há mais como correr contra as transformações, tentar fugir do inevitável. Como bem colocam Cox e Assis-Peterson (2007, p. 33): "O virgem, o nativo, o autêntico, o original, o puro, o não-misturado não existe mais. Aliás, nunca existiu”. Não existe língua pura: o vocabulário de qualquer língua do mundo é o resultado de séculos de intercâmbios com outros povos, outras culturas e, é claro, outras línguas (cf. BAGNO, 2001).

Não basta o professor deixar de descontar nota ou apenas "tolerar" os estrangeirismos, mas deve tratá-los como ocorrências inerentes à linguagem, considerando o fato de que as línguas humanas estão em constante movimento, por variação e mudança dentro da comunidade linguística, de uma geração para outra, sendo o contato entre dialetos e línguas uma força motriz comum e de grande relevância nesse processo.

Outro ponto a se refletir sobre os estrangeirismos é o fato de que empréstimos linguísticos sempre houve e sempre haverá. Ao contrário do que alguns professores pensam, os estrangeirismos sempre existiram, não foi a globalização que fez surgir esse fenômeno na nossa língua, apesar, é claro, de ter contribuído muito para a intensificação do seu uso, sobretudo com a potência da língua inglesa (e dos Estados Unidos, é claro) no mundo nas últimas décadas. Garcez e Zilles (2001, p. 29) afirmam que "Na visão alarmista de que os estrangeirismos representam um ataque à língua, está 
pressuposta a noção de que existiria uma língua pura, nossa, isenta de contaminação estrangeira. Não há". Não paramos para pensar que quase todo o léxico que temos hoje foi inicialmente estrangeiro. Assim como percebemos que novos elementos linguísticos que um dia já foram da nossa língua estão retornando, isto é, estão voltando a aparecer na fala dos brasileiros. Acontece que alguns professores consideram esses elementos como estrangeirismos, sem ao menos conhecer sua procedência.

Para Perini (2004, p. 13):

Não há o menor sintoma de que os empréstimos estrangeiros estejam causando lesões na língua portuguesa; a maioria, aliás, desaparece em pouco tempo, e os que ficam se assimilam. O português, como toda língua, precisa crescer para dar conta das novidades sociais, tecnológicas, artísticas e culturais.

A professora Juliana revela que prefere que seus alunos utilizem "a linguagem do nosso país, ao invés de usar muitos estrangeirismos". Isso significa que a professora não considera "do nosso país" as palavras que são usadas no Brasil, e sim oriundas de outras línguas que não o português. Mas o que fazer quando o aluno precise utilizar uma palavra que não tem tradução correspondente na língua portuguesa? Ora, temos diversas palavras portuguesas que há alguns anos não estavam em nosso léxico, mas que, com o passar do tempo, passaram a fazer parte da nossa língua. Bem sabemos que as palavras pênalti, gol, drible e futebol são palavras que se aportuguesaram, e considerá-las como estrangeiras hoje em dia seria negar uma identidade nacional.

Os estrangeirismos não alteram as estruturas da língua, a sua gramática. Por isso, não são capazes de destruí-la, como juram os conservadores. É o mesmo que temer que alguns desenhos coloridos pintados na fachada de um prédio possam fazê-lo desmoronar. Os estrangeirismos contribuem apenas no nível mais superficial da língua, que é o léxico. (BAGNO, 2001, p. 74).

\section{Considerações Finais}

Sempre existiram, na história das línguas mundiais, influências e contatos entre línguas, todas elas se influenciam mutuamente, e não é diferente com a língua portuguesa. Não podemos afirmar que houve, em algum momento na história da humanidade, uma língua que fosse completamente 
pura, virgem, homogênea, invariável, una e imutável. Isso porque onde existem línguas, existem mudanças e variações (até podemos dizer "contaminações", como preferem os puristas). É uma tarefa quixotesca tentar regular a mudança e o contato entre as línguas. É claro que as línguas não mudam por si só, somos nós, falantes, que agimos sobre elas e somos responsáveis por suas transformações e variações, em outras palavras: uma língua não existe sem os seus falantes (cf. CALVET, 2002). Uma língua só deixa de existir "quando a última pessoa que a fala desparece. Ou, algumas pessoas dizem, morre quando a penúltima pessoa que a fala desaparece, pois então a última não tem mais ninguém com quem conversar" (CRYSTAL, 2005, p. 60). cursos mais expressivos na língua, mas o que fazer quando eu não quero utilizar esses outros recursos? Quando a forma linguística que eu utilizo está dando conta das minhas necessidades de comunicação, isto é, quando meu enunciado é perfeitamente bem compreendido pelo outro? E que tipos de exercícios nós, professores de português, poderíamos fazer, como afirma a professora Juliana, que possam evitar determinadas manifestações linguísticas que já estão mais do que na hora de serem adotadas por nossas gramáticas? E o mais importante: por que fazer exercícios para tentar "corrigir" as falas dos nossos alunos e eliminar de seus vocabulários alguns fenômenos linguisticamente complexos sendo que esses fenômenos jamais deveriam ser considerados erros? Não seria querer colocar gesso em uma perna que nunca fora quebrada? Estas são indagações que colocamos a nós mesmo e a todos os professores de língua materna.

Acabamos por fortalecer, em sala de aula, regras e crenças linguísticas baseadas em mitos, em folclores linguísticos (cf. BAGNO, 2001) que apenas reforçam a intolerância linguística. Fortificamos essa falsa noção de erro ao tentarmos imbuir no aluno conceitos de uma língua inatingível, intocável, inalcançável, uma língua utópica, sem percebermos que essa é a nossa língua portuguesa, nosso português real e ele, como afirma Bagno (2001, p. 70) “'não vai bem, obrigado', nem 'vai mal, coitado': ele simplesmente vai, segue seu rumo, seu fluxo ditado por suas próprias forças constitutivas internas e pela ação de seus falantes de carne e osso, cabelo e dente".

\section{Referências}

ALKMIM, T. M. Sociolinguística. In: MUSSALIM, F.; BENTES, A. C. (orgs.). Introdução à Linguística: Domínios e fronteiras. 8. ed. São Paulo: Cortez, 2008. 
ANTUNES, I. Aula de Português: Ensino e Interação. São Paulo: Parábola, 2003.

BAGNO, M. Preconceito linguístico: O que é, como se faz. 22. ed. São Paulo: Loyola, 1999.

. Cassandra, Fênix e outros mitos. In: FARACO, C. A. (org.). Estrangeirismos: guerras em torno da língua. São Paulo: Parábola, 2001.

. A norma oculta: Língua e poder na sociedade brasileira. 7. ed. São Paulo: Parábola, 2003.

. Por uma Linguística militante. In: BORTONI-RICARDO. Educação em Língua Materna: a Sociolinguística na sala de aula. São Paulo: Parábola, 2004.

BATISTA, A. A. G. A avaliação dos livros didáticos: Para entender o Programa Nacional do Livro Didático. In: BATISTA, A. A. G.; ROJO, R. (orgs.). Livro Didático de língua portuguesa, letramento e cultura escrita. São Paulo: Mercado de Letras, 2003.

BORTONI-RICARDO, S. M. Educação em Língua Materna: a Sociolinguística na sala de aula. São Paulo: Parábola, 2004.

CALVET, L. J. Sociolinguística: Uma introdução crítica. Trad. Marcos Marcionilo. São Paulo: Parábola, 2002.

COSTA, S. B. B. Viva a Fala Brasileira! A Tarde. Salvador, 16 jun. 2007. Caderno Cultural, p. 11. glossia: para compreender o fenômeno das fricções linguístico-culturais em sociedades contemporâneas sem nostalgia. In: CAVALCANTI, M. C.; BORTONI-RICARDO, S. M. (Orgs.). Transculturalidade, linguagem e educação. Campinas, SP: Mercado de Letras, 2007.

CRYSTAL, D. A Revolução da Linguagem. Trad. Ricardo Quintana. Rio de Janeiro: Jorge Zahar Ed., 2005.

FARACO, C. A. Por uma pedagogia da variação linguística. In: CORREA, 
D. A. (Org.). A Relevância Social da Linguística: Linguagem, teoria e ensino. São Paulo: Parábola; Ponta Grossa, PR: UEPG, 2007.

FIORIN, J. L. Considerações em torno do projeto de lei no 1676/99. In: FARACO, C. A. (Org.). Estrangeirismos: guerras em torno da língua. São Paulo: Parábola, 2001.

GARCEZ, P. M.; ZILLES, A. M. Estrangeirismos: desejos e ameaças. In: FARACO, C. A. (Org.). Estrangeirismos: guerras em torno da língua. São Paulo: Parábola, 2001.

GREGOLIN, M. R. O que quer, o que pode esta língua? Teorias linguísticas, ensino de língua e relevância social. In: CORREA, D. A. (Org.). A Relevância Social da Linguística: Linguagem, teoria e ensino. São Paulo: Parábola; Ponta Grossa, PR: UEPG, 2007.

LEITE, M. Q. Preconceito e intolerância na linguagem. São Paulo: Contexto, 2008.

MACHADO FILHO, A. V. L. Gerundindo. Jornal Número G, [s.1.], ano 1, n.1, maio/junho de 2005 .

MARCUSCHI, L. A. Produção textual, Análise de gêneros e Compreensão. São Paulo: Parábola, 2008.

PERINI, M. A. A língua do Brasil amanhã e outros mistérios. São Paulo: Parábola, 2004.

POSSENTI, S. A questão dos estrangeirismos. In: FARACO, C. A. (org.). Estrangeirismos: guerras em torno da língua. São Paulo: Parábola, 2001.

. Defendendo o Gerúndio. In: Discutindo Língua Portuguesa. Ano I, $\mathrm{n}^{\circ}$ 1, Escala Educacional ISSN 1809-0230 (s/d). 2008.

ROCHA, L. C. A. Gramática: nunca mais: O ensino da língua padrão sem o estudo da gramática. São Paulo: WMF Martins Fontes, 2007.

SCHERRE, M. M. P. Doa-se lindos filhotes de poodle: Variação linguística, mídia e preconceito. 2. ed. São Paulo: Parábola, 2008. 
SCHIMITZ, J. R. Sobre o gerúndio e o "gerundismo": Uma análise de um assunto emotivo e polêmico. Confluência: Revista do Instituto da Língua Portuguesa. N. 31, sem. 1. Rio de Janeiro, 2006.

SERAFIM, R. L. Do Gerúndio ao gerundismo: mudança e preconceito linguístico. Salvador, BA: UFBA, 2008. Monografia - Universidade Federal da Bahia, Salvador, 2008.

Recebido em: agosto de 2012.

Aprovado em: janeiro de 2013. 